\title{
Students' Attitudes Based on Adoption of Scientific Attitudes and Interested Expanding Time Learning Science
}

\author{
E. Erika, Edwin Kurniawan, Azizah Hanum \\ Physics Education, Faculty of Teacher Training and Education, Universitas Jambi, \\ Indonesia
}

*Corresponding Author Email: erk.erikaaaaa@gmail.com

\begin{abstract}
Article History
Key Words

attitudes; scientific attitudes; natural of science
\end{abstract}

Received: November 2020

Accepted: December 2020

Published: December 2020

How to cite this article?

\begin{abstract}
The purpose of this research was to look at the description of scientific attitudes possessed by students at SMPN 17 jambi city based on indicators of adoption of scientific attitudes and indicators of interest in increasing the time of science learning. This research is a quantitative study in which researchers use survey methods with data collection techniques using a questionnaire. The results of the 2 attitude indicators discussed in this study are indicators of the adoption of scientific attitudes of $62.5 \%$ of students categorized as good. While the interest in increasing science learning time by $66.4 \%$ of students is of sufficient category. Based on the results of research that has been conducted it can be concluded that students have adopted a good scientific attitude and have sufficient interest to increase their science learning time.
\end{abstract}

Erika, E., Kurniawan, E., \& Hanum, A. (2020). Students' Attitudes based on Adoption of Scientific Attitudes and Interested Expanding Time Learning Science. Lensa: Jurnal Kependidikan Fisika, 8(2), 70-75. doi:https://doi.org/10.33394/j-1kf.v8i2.2952

\section{INTRODUCTION}

According to Widiyatmoko and Pamelasari (2012), science (natural science) is knowledge obtained through observation, data collection during experiments and education in order to produce reliable explanations of symptoms. In junior high school (junior high school), students generally perceive science as a fairly boring and scary subject. Especially if it is added to the habit of teachers who feed students with various formulas that are difficult to understand (Astuti, Sunarno, \& Sudarisman, 2012). In essence, science mastery must be instilled since elementary school (elementary school) so that students are able to apply science at the next level.

This fear will affect learning outcomes and achievements as well as the achievement of students in learning science (Yusif, 2010). Not only affects learning outcomes, but these words also make it difficult for students to learn in the future. Fear and boring also make students become pessimistic, apathetic and even lazy to learn science. To see students' attitudes towards science subjects, we can use several aspects of attitude indicators such as adoption of scientific attitudes and interest in increasing science learning time (Putra, Lumbantoruan \& Samosir, 2019).

According to Astalini et al (2018), the adoption of a scientific attitude is an attitude that scientists must have such as curiosity, fear, being honest and accepting the truth through proving facts. The adoption of a scientific attitude aims to measure the willingness and readiness of students to new information. According to Fakhrudin (2010) in Astalini et al (2018), developing a scientific attitude can help students get better learning outcomes. 
According to Astalini et al (2018), the interest in increasing the time for learning science shows how interested and serious the students are in understanding and studying science. If students spend more time learning science, it will help these students understand science subjects. One of the efforts to make students want to increase their time to study science is encouragement such as interest and pleasure in learning science. We can say that students who like science will have a great interest in learning science. And conversely, students who do not like science will not be interested in increasing their time in learning science so that this has an impact on poor learning outcomes in science subjects. These poor learning outcomes will also affect students' interest and desire in learning science.

Based on research conducted by Putra, Lumbantoruan and Samosir in 2019 that knowing student attitudes in learning physics is important, the research results were obtained from indicators of adoption of scientific attitudes with a good category with a percentage of $55.2 \%$. The indicators of interest in increasing the time to study physics and a career interest in physics were categorized as sufficient in the percentage of $72 \%$ and $68 \%$. There are differences in the research I did between previous studies, namely the measured attitude indicators and subjects.

\section{METHOD}

This research was conducted at SMP Negeri 17 Jambi City. The implementation time of this research is January 2020. This research is a quantitative study, namely the researcher uses a survey method with data collection techniques using a questionnaire. The subjects in this study were students at SMP Negeri 17 Jambi City, class 2020/2021, which totaled 128 respondents. Samples were taken based on the total sampling technique.

This study used a questionnaire instrument adopted from Astalini and Kurniawan (2019). According to Istijanto (2005) a questionnaire is a list of questions used by researchers to obtain data directly from sources using a communication process by asking questions. In this study, researchers used a closed questionnaire that was direct. This means that the respondent answers about himself and is not given the opportunity to answer based on his own language.

The attitude questionnaire that the researcher adopted from Astalini and Kurniawan (2019) has 56 statements describing the positive attitudes and negative attitudes of students towards science learning. 56 statements are divided into several indicators. The indicators studied by the researcher were the adoption of scientific attitudes totaling 7 statements, namely statements numbered $3,10,16,23,28,35$ and 48 . As well as the interest in increasing the time to study science amounted to 8 statements, there are numbers 5,12 , $18,25,30,37,43$ and 50. Statement items can be seen in the Table 1.

Tabel 1. Pernyataan yang digunakan

\begin{tabular}{ll}
\hline Adoption of a scientific stance & $\begin{array}{l}\text { The interest in increasing the time to } \\
\text { study science }\end{array}$ \\
\hline $\begin{array}{l}\text { I enjoy reading about things that don't fit } \\
\text { my previous thinking. }\end{array}$ & $\begin{array}{l}\text { I want to be a science extracurricular } \\
\text { member. }\end{array}$ \\
$\begin{array}{l}\text { I don't like to repeat an experiment when } \\
\text { I'me results are the same. }\end{array}$ & $\begin{array}{l}\text { TV when I'm at home. } \\
\text { I am curious about the world we live in. }\end{array}$ \\
$\begin{array}{l}\text { I want to be given a science book or } \\
\text { scientific kit as a gift. }\end{array}$ \\
important.
\end{tabular}




\begin{tabular}{ll}
\hline Adoption of a scientific stance & $\begin{array}{l}\text { The interest in increasing the time to } \\
\text { study science }\end{array}$ \\
\hline $\begin{array}{l}\text { I like to listen to people whose opinions } \\
\text { differ from mine. }\end{array}$ & $\begin{array}{l}\text { I want to do science experiments at home. } \\
\text { I feel bored hearing new thoughts }\end{array}$ \\
$\begin{array}{ll}\text { I don't want to change my idea even to friends about science after school } \\
\text { can be boring }\end{array}$ \\
$\begin{array}{ll}\text { I enjoy activities in the science laboratory } \\
\text { idea }\end{array}$ & $\begin{array}{l}\text { Listening to science talk on the radio can be } \\
\text { boring. }\end{array}$ \\
\hline
\end{tabular}

The scale used is the Likert scale. According to Syofian et al (2015), the Likert scale is a scale with various levels of agreement to statements. In the attitude questionnaire the adoption researcher has five scale choices, namely STS (Strongly Disagree), TS (Disagree), $\mathrm{N}$ (Neutral), S (Agree) and SS (Strongly Agree). To conduct this research, the first thing the researcher did was to distribute a questionnaire in the form of a questionnaire. So after distributing the questionnaire, we will get the data. Furthermore, we analyze the data using descriptive statistics. According to Rosana and Setyawarno (2016) in general, descriptive statistics are used to describe data characteristics in the form of averages and data variants. The ranges used in the attitude questionnaire are shown in the Table 2 below.

Table 2. Indicators, Range, and Attitude Questionnaire Statement Items on Science Subjects

\begin{tabular}{cccc}
\hline Category & Range & $\begin{array}{c}\text { Adopt a scientific } \\
\text { attitude }\end{array}$ & $\begin{array}{c}\text { Interest in increasing the } \\
\text { time to study science }\end{array}$ \\
\hline Not very good & $9.0-16.2$ & & \\
\hline Not good & $16.3-23.4$ & & \\
\hline enough & $23.5-30.6$ & $3,10,16,23,28,35,48$ & $5,12,18,25,30,37,43,50$ \\
\hline good & $30.7-37.8$ & & \\
\hline Very good & $37.9-45.0$ & &
\end{tabular}

To describe these characteristics, the data were analyzed using SPSs 25. And what will be obtained is the percentage and maximum and minimum values. This study aims to obtain a picture of the adoption of scientific attitudes and a description of interest in increasing the time to study science.

\section{RESULTS AND DISCUSSION}

According to Lumbantoruan and Jannah (2019), the success of education can be seen from the development of achievements or changes in attitudes of students. When the students' attitudes are positive, the science learning concept will be easily accepted by students. To see the attitudes and achievements of students, the researchers reviewed two indicators, namely the adoption of a scientific attitude and an interest in increasing the science learning time. Each individual or student will certainly show a diverse response to stimulants (Guido, 2013).

The novelty of this research is that there is no research conducted at SMPN 17 Jambi City regarding student attitudes towards science subjects in terms of indicators of adoption of scientific attitudes and interest in increasing science learning time. The indicators used were derived from research by Fraser (1981) which was then implemented in Indonesia 
through research from Astalini and Kurniawan (2019). The following is a description of the research results obtained (Table 3).

Table 3. Overview based on indicators of adoption of scientific attitudes

\begin{tabular}{cccc}
\hline No & Range & Frequency & Percentage (\%) \\
\hline $\mathbf{1}$ & $7.0-12.6$ & 0 & 0 \\
$\mathbf{2}$ & $12.7-18.2$ & 0 & 0 \\
$\mathbf{3}$ & $18.3-23.8$ & 21 & 16.4 \\
$\mathbf{4}$ & $23.9-29.4$ & 80 & 62.5 \\
$\mathbf{5}$ & $29.5-35.0$ & 27 & 21.1 \\
\hline & Summary & $\mathbf{1 2 8}$ & $\mathbf{1 0 0}$ \\
\hline
\end{tabular}

Table 3 shows the results of the figures based on indicators of adoption of scientific attitudes. For the range 7.0 - 12.6 it is called the very bad category. In the results of the study, we see that $0 \%$ of students who do not have a scientific attitude adopt an attitude. For the range $12.7-18.2$ it is called the bad category. In this category $0 \%$ of students have bad attitudes about the adoption of scientific attitudes. For the range $18.3-23.8$ it is a fairly good category, which is $16.4 \%$ of students. Furthermore, the good category, namely in the range $23.9-29.4$ there were $62.5 \%$ of students. And the range $29.5-35.0$ is a good category, namely there are $21.1 \%$ of students who have adopted a good scientific attitude. We can say that the majority of students are categorized as good and very good on the indicators of adoption of a scientific attitude, which is $83.6 \%$ while the remaining $16.4 \%$ is categorized as sufficient. We can also say that students already have a scientific mindset in their lives.

Based on the research that has been done, students have instilled a scientific mindset in their lives. Most of the students like to read about things they don't know about science. It can also be seen that students are diligent and enthusiastic when science learning begins, such as during experiments. That most of the students want to do experiments until the results are as they expect. It is clear that the student has adopted a scientific attitude at SMPN 17 Jambi City. This dimension of attitude should be possessed by students at SMPN 17 Jambi City in science subjects. Because the adoption of a scientific attitude will have an impact on other attitudes (Table 4).

Table 4. An overview based on interest in increasing science learning time

\begin{tabular}{cccc}
\hline No & Range & Frequency & Percentage (\%) \\
\hline $\mathbf{1}$ & $8.0-14.4$ & 0 & 0 \\
$\mathbf{2}$ & $14.5-20.8$ & 4 & 3.1 \\
$\mathbf{3}$ & $20.9-27.2$ & 85 & 66.4 \\
$\mathbf{4}$ & $27.3-33.6$ & 36 & 28.1 \\
$\mathbf{5}$ & $33.7-40.0$ & 3 & 2.3 \\
\hline & Summary & $\mathbf{1 2 8}$ & $\mathbf{1 0 0}$ \\
\hline
\end{tabular}

Table 4 shows the results of an attitude of interest in increasing science learning time. The range 8.0-14.4 is the range for the bad category with a percentage of $0 \%$. The range of $14.5-20.8$ is the range for the unfavorable category with a percentage of $3.1 \%$. Furthermore, the range 20.9-27.2 is a fairly good category with a percentage of 66.4 . The range 27.3-33.6 is the range for the good category with a percentage of $28.1 \%$ and the range 33.7-40.0 is the range for the very good category with a percentage of $2.3 \%$.

We can say that students are more likely to be neutral or sufficient when increasing their science learning time, namely $66.4 \%$. This shows that students are still less interested in spending more time exploring the science field. Increasing the time to study science, 
can improve student learning outcomes in science subjects. Because students who are trained to work on science questions will be faster and more proficient in deciding which concepts or formulas to use. It is clear from the research results that most students are neutral and kind. However, there are $3.1 \%$ of students who do not like science learning.

Students who add more time to studying Science will like or love science lessons, because students who are happy about something are definitely interesting to find out more about what they like. This also applies to science lessons, students who enjoy science lessons will certainly look deeper into the material explained by the teacher. So that the student's independent learning process is very good and student learning outcomes at school will increase with the addition of other learning times besides in class

\section{CONSLUSSION}

Based on the results of research that has been conducted regarding attitudes using indicators of adoption of scientific attitudes and interest in increasing science learning time at SMPN 17 Jambi City, it can be said that students have adopted a good scientific attitude, which is $62.5 \%$. Students already have a scientific mindset. Not only have they adopted a good scientific attitude, students also have sufficient interest to increase their science learning time, which is $66.4 \%$. But there are also $3.1 \%$ of students who do not really like science lessons.

\section{RECOMMENTATION}

The suggestion for the school is to pay more attention to students' attitudes towards science, because it has an impact on student learning outcomes.

\section{ACKNOWLEDGMENTS}

This research received no specific grant from any funding agency in the public, commercial, or not for profit sectors.

\section{REFERENCES}

Astalini, A., Kurniawan, D. A., \& Nurfarida, L. Z. (2018). Deskripsi sikap siswa SMA di Batanghari berdasarkan indikator normalitas ilmuwan, adopsi dari sikap ilmiah, ketertarikan memperbanyak waktu, dan ketertarikan berkarir di bidang fisika. Jurnal $\begin{array}{lllll}\text { Riset Dan Kajian Pendidikan } & 73 .\end{array}$ https://doi.org/10.12928/jrkpf.v5i2.10736

Astalini, A., \& Kurniawan, D. A. (2019). Pengembangan Instrumen Sikap Siswa Sekolah Menengah Pertama Terhadap Mata Pelajaran Ipa. Jurnal Pendidikan Sains (Jps), 7(1), 1. https://doi.org/10.26714/jps.7.1.2019.1-7

Astuti, R., Sunarno, W., \& Sudarisman, S. (2012). Keterampilan Proses Sains Menggunakan Metode Eksperimen Bebas Termodifikasi Dan Eksperimen Terbimbing Ditinjau Dari Sikap Ilmiah Dan Motivasi Belajar Siswa. Eprints.Uns.Ac.Id, 1(1). Retrieved from https://eprints.uns.ac.id/1210

Guido, M. D. (2013). Attitude and Motivation towards Learning Physics. 2(11), 20872094

Istijanto. (2005). Riset Sumber Daya Manusia, Cara Praktis Mendeteksi DimensiDimensi Kerja karyawan. PT. Gramedia Pustaka Utama. Jakarta.

Lumbantoruan, A., \& Jannah, N. (2019). Deskripsi Sikap Peserta Didik Terhadap Fisika. 5(2). https://doi.org/10.32699/spektra.v5vi2i.109

Putra, D. S., Lumbantoruan, A., \& Samosir, S. C. (2019). Deskripsi sikap siswa: adopsi sikap ilmiah, ketertarikan memperbanyak waktu belajar fisika dan ketertarikan 
berkarir di bidang Fisika. Tarbiyah: jurnal ilmiah kependidikan, 8(2), 91-100.

Rosana, D., \& Setyawarno, D. (2016). Statistik terapan untuk penelitian pendidikan. yogyakarta.

Syofian, S., Setiyaningsih, T., Syamsiah, N., Informatika, T., Teknik, F., \& Persada, U. D. (2015). Otomatisasi metode penelitian skala likert berbasis web. Jurnal.Ftumj.Ac.Id/Index.Php/Semnastek, (November), 1-8.

Widiyatmoko, A., \& Pamelasari, S. D. (2012). Pembelajaran berbasis proyek untuk mengembangkan ALAT peraga IPA dengan memanfaatkan bahan bekas pakai. Jurnal Pendidikan IPA Indonesia, 1(1), 51-56. https://doi.org/10.15294/.v1i1.2013

Yusuf, M. (2010). Peningkatkan Hasil Belajar Matematika Siswa melalui Lembar Kerja Siswa (LKS) Interaktif Berbasis Komputer di SMA Muhammadiyah 1 Palembang. Jurnal Pendidikan Matematika, 4(2), 34-44. 